\title{
In Vitro Clonal Propagation of a Fast Growing Legume Tree-Acacia mangium Willd. Employing Cotyledonary Node Explants
}

\author{
Muhammad SHAHINOZZAMAN*, Mustafa Abul Kalam AZAD, Muhammad Nurul AMIN \\ University of Rajshahi, Faculty of Life and Earth Science, Department of Botany, Rajshahi-6205, \\ Bangladesh; mshahin81@gmail.com (*corresponding author)
}

\begin{abstract}
An efficient protocol for in vitro clonal propagation of $A$. mangium was developed using seedling derived explants. Out of three different explants tested for shoot proliferation, cotyledonary node showed best performance than leaf node and shoot tip explants. MS (Murashige and Skoog's) medium was found best for shoot proliferation and cotyledonary nodes were subsequently cultured on MS medium supplemented with BA and $\mathrm{Kn}$ alone or in combination with NAA, IBA and GA at different concentrations. Maximum number of shoots was formed on MS medium containing $4.0 \mu \mathrm{MBA}$. For adventitious rooting, in vitro proliferated shoots were transferred to full strength MS medium fortified with IBA and NAA singly at different concentrations $(0-8.0 \mu \mathrm{M})$. Best rooting responses were observed in the medium containing $8.0 \mu \mathrm{M}$ IBA. Plantlets having well developed root system were transferred to soil and successfully acclimatized with $65 \%$ survival rate under ex vitro condition.
\end{abstract}

Keywords: in vitro propagation, multipurpose legume tree, plantation forestry, seedling explants

\section{Introduction}

A. mangium Willd., belonging to Mimosaceae family, is one of the most important leguminous tree characterized by its fast growth, nitrogen fixing ability, good growth in adverse soil condition and a tendency to grow well in humid and hot climate (Umezawa et al., 2008). It is native to northern Queensland of Australia, through Papua New Guinea into the Indonesian provinces of Irian Jaya and Maluku. This tree species is now widely used for timber, pulp and fire wood (Galiana et al., 1991). In addition, its bark contains considerable amount of antioxidant phenols (Zhang et al., 2010) offering increasing demand of its bark in different industries as a source of active substance for cosmetic and pharmaceutical composition. Taking into account of its different valuable characteristics, such as fast growth, good growth in adverse soil condition, good quality pulp and fuel-wood production etc., this tree species was introduced into Bangladesh from Australia during 1980s (Islam, 2003). Besides, several reports (Amin et al., 1995; Hossain et al., 1997; Khan et al., 2004) recommended this species suitable for afforestation and reforestation in degraded hilly areas, marginal lands and roadside plantations in Bangladesh.

Conventional propagation methods like using seeds, cutting, grafting etc. have limited scope for large scale propagation of $A$. mangium because of poor seed germination and poor rooting ability of cuttings. Compare to conventional propagation methods, in vitro clonal propagation is a common technique, which has been extensively applied in large scale multiplication of many important forest tree species (Ahuja, 1993; Bonga et al., 1992). Due to having recalcitrance nature of adult tissues, however, most of the investigations on in vitro clonal propagation of forest legumes are concentrated on juvenile materials especially on seedling derived explants. There are a few successful reports on in vitro clonal propagation of $A$. mangium using seedling derived explants like seedling nodes (Ahmad, 1991; Galiana et al., 1991; Saito et al., 1993), but no noted reports on its clonal propagation employing cotyledonary node explants have been found yet. This communication, therefore, describes a successful and quick method on large scale in vitro clonal propagation of $A$. mangium via cotyledonary node explants.

\section{Materials and methods}

Seeds of $A$. mangium were collected from a mature elite tree grown in Rajshahi University campus, Rajshahi, Bangladesh. Seeds were washed thoroughly under running tap water for 15 minutes and then washed with continuous agitation in a few drops Savlon ${ }^{\text {Ts }}$ containing water for 15 minutes. Washed seeds were pre-treated by immersing them in boiling water for 2-5 minutes followed by soaking in cold water for 20 minutes. The pre-treated seeds were then treated with $0.1 \% \mathrm{HgCl}_{2}$ for 5 minutes under laminar air flow cabinet to disinfect them. Finally, seeds were washed 3 to 5 times with sterile distilled water and were placed in culture tubes $(25 \times 150 \mathrm{~mm})$ containing hormone free MS (Murashige and Skoog, 1962) medium prepared with $3 \%(\mathrm{w} / \mathrm{v})$ sucrose and $0.8 \%(\mathrm{w} / \mathrm{v})$ agar (Sigma Chemical Co. USA). The $\mathrm{pH}$ of the medium was adjusted 
80

to 5.7 before autoclaving at $121^{\circ} \mathrm{C}$ for 20 minutes at 1.2 $\mathrm{kg} / \mathrm{cm}^{2}$ pressure. After successful germination of seeds, three different types of explants viz. cotyledonary node, leaf node and shoot tip (1-1.5 cm in length) were excised from 2-week-old seedlings (Fig. 1A) and cultured on MS basal medium containing $4.0 \mu \mathrm{M} \mathrm{BA}(6-\mathrm{Benzyl}$ adenine) alone or in combination with $0.5 \mu \mathrm{MNAA}(\alpha$-naphthalene acetic acid) to test the effect of explants on in vitro shoot multiplication.

To test the effect of basal medium on in vitro shoot multiplication, cotyledonary nodes were initially cultured on four different basal medium viz. MS, MMS, $\mathrm{MMS}_{2}$ and WPM (Woody plant medium) (Lloyd and McCown, 1980) supplemented with $4.0 \mu \mathrm{M}$ BA. In addition, excised cotyledonary nodes of 2-week-old seedlings were cultured on MS medium containing various concentrations (2.0$8.0 \mu \mathrm{M})$ of BA and $\mathrm{Kn}$ (6-furfurylamino purine). Different concentrations $(0.5-2.0 \mu \mathrm{M})$ of NAA, IBA (Indole-3butyric acid) and $\mathrm{GA}_{3}$ (Gibberellic acid) were combined with $4.0 \mu \mathrm{M}$ BA to test their shoot induction efficiency.

Microshoots of 1-3 cm length were prepared from usable shoots by snipping off the basal leaves and cultured them individually in $25 \times 150 \mathrm{~mm}$ culture tubes with 15 $20 \mathrm{ml}$ of full strength MS medium supplemented with NAA or IBA $(2.0-8.0 \mu \mathrm{M})$.

The rooted plantlets were transferred on to the small plastic pots containing sterilized soil mix (garden soil and compost in 1:1 ratio). Transferred plantlets were hardened in growth chamber condition for 25 days and then transferred to outdoor condition. The total number of plants transferred to the pots and the number of surviving plants in the outdoor condition were recorded.

All the cultures were maintained at $25 \pm 2^{\circ} \mathrm{C}$ under a $16 \mathrm{~h}$ light and $8 \mathrm{~h}$ dark cycle with the light intensity of 2000-3000 lux provided by cool-white fluorescent tubes $(36 \mathrm{~W})$. Data were recorded after 8 weeks of culture except for rooting experiment when the data were recorded after 4 weeks of incubation. In all the experiments, 12-15 explants were used and each experiment was repeated three times. Mean and standard error were calculated for all numerical data. The mean data of each treatment were compared by using Duncan's Multiple Range Test (DMRT) at $\mathrm{P}=0.05 \%$.

\section{Results and discussion}

Cotyledonary node showed the best shoot proliferation efficiency irrespective of media type, which followed by leaf node and shoot tip explants (Tab. 1). Cotyledonary nodes showed the maximum $99.33 \pm 0.67 \%$ response and produced $5.10 \pm 0.58$ shoots on $\mathrm{MS}+4.0 \mu \mathrm{M} \mathrm{BA}$ (Fig. 1B) while the highest $80.67 \pm 1.33 \%$ leaf nodes and $51.67 \pm 1.28 \%$ shoot tips formed maximum $1.50 \pm 0.40$ and $0.70 \pm 0.33$ shoots, respectively on the same media formulation. Results of this experiment indicated the high regenerative capacity of cotyledonary node explants of
A. mangium than leaf node and shoot tip explants. Similar results were noted in a range of legume species, such as $A$. senegal (Khalafalla and Daffalla, 2008), A sinuata (Vengadesan et al., 2002b), Clitoria ternatea (Barik et al., 2007), Colutea istria (Hegazi and Gabar, 2010), Dalbergia sissoo (Pradhan et al., 1998a), D. latifolia (Pradhan et al., 1998b), Pterocarpus marsupium (Anis et al., 2005), $P$. santalinus (Rajeswari and Paliwal, 2008) and Peltophorum pterocarpum (Uddin et al., 2005). On the contrary of these findings, Amin et al. (1992) in carambola, Ara et al. (1991) in Sesbania grandiflora, Loh and Rao (1989) in guava and Rahman and Blake (1988) in jackfruit observed increased shoot proliferation from the seedling explants rather than cotyledonary nodes. Debergh and Read (1990) suggested that differential responses of different explants of the same plant are more species specific while Lane (1978) proposed the endogenous hormone level in buds of different regions of the stem as a reason of differential responses of different explants of the same plant. In case of $A$. mangium, further investigations, based on the present findings, should be carried out to find out the specific reason behind the differential responses of different explants.

The full strength MS medium affected shoot proliferation from cotyledonary node explants significantly than other three media (WPM, MMS 1 and MMS $)$ tested. Maximum $98.67 \pm 0.37 \%$ explants produced highest 3.93 \pm 0.37 shoots on MS medium. Although explants produced longest shoots $(1.63 \pm 0.34 \mathrm{~cm})$ in WPM medium, but both percentage of response and multiplication rate were lower in this medium than full strength MS medium. This study revealed that full strength MS medium was preferred for axillary shoot proliferation from cotyledonary nodes of $A$. mangium while WPM showed a little effect in terms of shoot proliferation. Full strength MS medium has been proved best for axillary shoot proliferation in many other Acacia species, including $A$. albida (Ruredzo and Hanson, 1993), A. catechu (Kaur et al., 1998), A. mearnsii (Huang et al., 1994), A. nilotica (Abbas et al., 2010), $A$. salicina, A. saligna and $A$. sclerosperma (Jones et al., 1990). Similar results were also observed in some other woody

Tab. 1. Effects of three different explants, cultured on MS medium containing $4.0 \mu \mathrm{M}$ BA alone or in combination with $0.5 \mu \mathrm{M}$ NAA, on axillary shoot proliferation of $A$. mangium

\begin{tabular}{cccc}
\hline $\begin{array}{c}\text { Type of } \\
\text { explant }\end{array}$ & $\begin{array}{c}\text { Plant growth } \\
\text { regulators }(\mu \mathrm{M})\end{array}$ & $\begin{array}{c}\text { Percentage of } \\
\text { explant responded } \\
(\mathrm{X} \pm \mathrm{SE})\end{array}$ & $\begin{array}{c}\text { Number } \\
\text { of shoots } \\
(\mathrm{X} \pm \mathrm{SE})\end{array}$ \\
\hline $\begin{array}{c}\text { Cotyledonary } \\
\text { node }\end{array}$ & BA 4.0 & $99.33 \pm 0.67 \mathrm{a}$ & $5.10 \pm 0.58 \mathrm{a}$ \\
\hline Leaf node & BA 4.0 & $80.67 \pm 1.33 \mathrm{c}$ & $1.50 \pm 0.40 \mathrm{bc}$ \\
\hline Shoot tip & BA $4.0+$ NAA 0.5 & $80.00 \pm 1.61 \mathrm{c}$ & $1.20 \pm 0.29 \mathrm{~cd}$ \\
\hline & BA 4.0 & $51.67 \pm 1.28 \mathrm{~d}$ & $0.70 \pm 0.33 \mathrm{~cd}$ \\
\hline
\end{tabular}

Note: Values represent means \pm standard error of 20 explants per treatment in three repeated experiments. Means followed by the same letters are not significantly different by Duncan's multiple Range Test at $0.05 \%$ probability level 


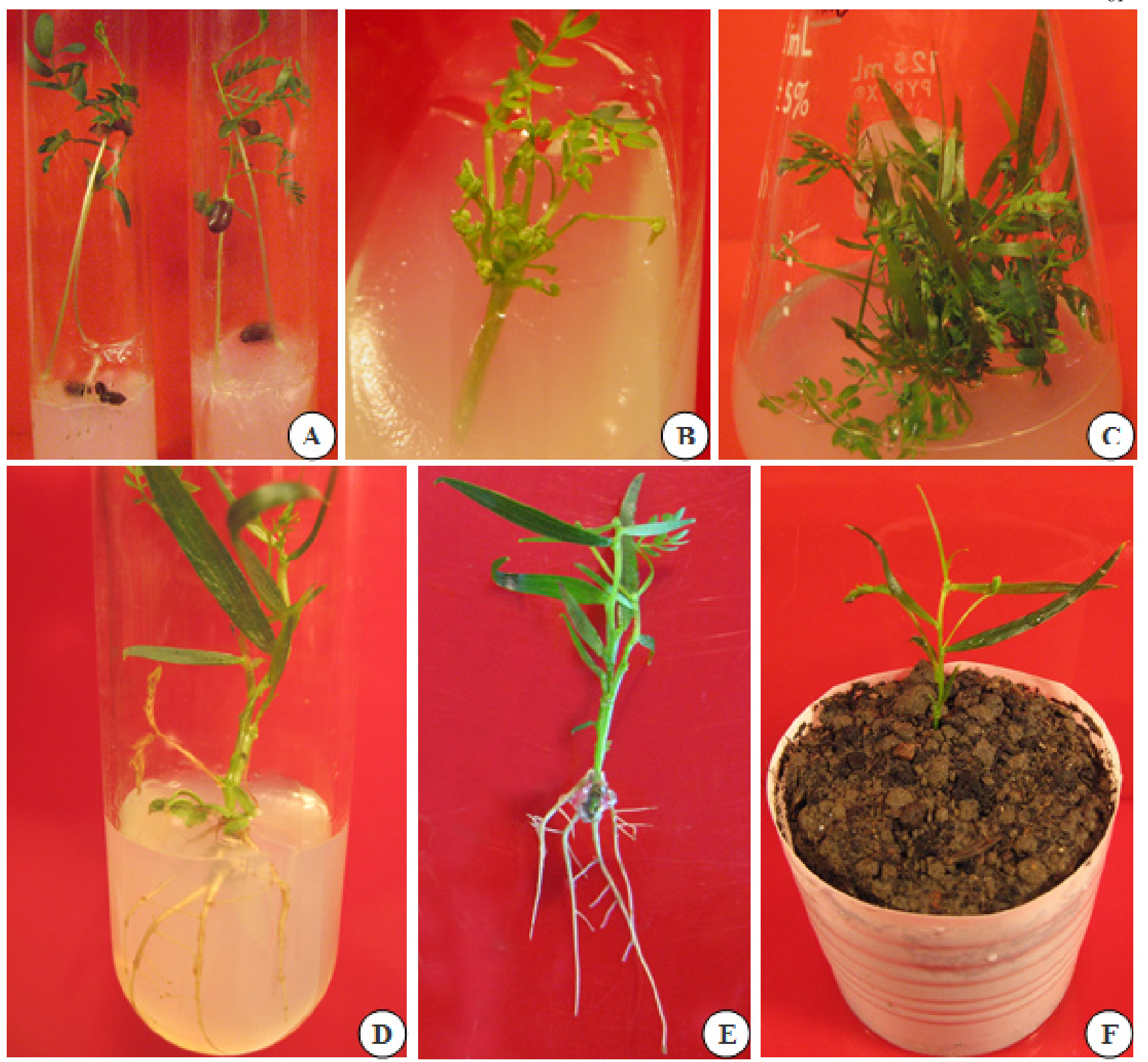

Fig. 1. In vitro propagation of $A$. mangium Willd. from cotyledonary node explants. A. Two-week old aseptically germinated seedlings; B. Multiple shoot formation from cotyledonary node explant after 4 weeks of culture on MS + 4.0 $\mu \mathrm{M}$ BA; C. In vitro proliferated shoots from cotyledonary node explant after 8 weeks of culture on MS + 4.0 $\mu \mathrm{M} \mathrm{BA}$; D. Rooted plantlets ready for transplantation; E. Acclimatized plantlets after 7 days of transplantation onto soil mix

trees, like Colutea istria (Hegazi and Gabr, 2010), Dalbergia latifolia (Swamy et al., 1992), Lagerstromia parviflora (Tiwari et al., 2002), Pterocarpus marsupium (Hussain et al., 2008), P. santalinus (Rajeswari and Paliwal, 2008), Sterculia urens (Hussain et al., 2007) and Swartzia madegascariensis (Berger and Schaffner, 1995).

Cotyledonary node explants cultured on MS medium devoid of growth regulator produced $0.92 \pm 0.19$ shoots with $0.64 \pm 0.14 \mathrm{~cm}$ lengths, which may be due to the presence of endogenous cytokinin in cotyledonary nodes, suggested by Rajeswari and Paliwal (2008) in Pterocarpus santalinus. However, the addition of exogenous cytokinin to MS medium induced shoot multiplication rate remarkably, indicating the requirement of exogenous cytokinin supply in the medium for better axillary shoot proliferation. Out of two different cytokinin-BA and $\mathrm{Kn}$, best shoot proliferation was observed on medium containing BA. Highest number of shoots $(4.08 \pm 0.60)$ and longest shoots $(1.20 \pm$ $0.15 \mathrm{~cm}$ ) were formed on $4.0 \mu \mathrm{M} \mathrm{BA}$ containing medium (Fig. 1. C) while $3.25 \pm 0.43$ shoots with maximum $1.16 \pm$ $0.18 \mathrm{~cm}$ length were found in medium containing $6.0 \mu \mathrm{M}$ $\mathrm{Kn}$. The results indicated that BA was superior to $\mathrm{Kn}$ for axillary shoot proliferation from cotyledonary nodes of $A$. mangium. The superiority of $\mathrm{BA}$ over $\mathrm{Kn}$ has also been reported in in vitro propagation of other species of Acacia (Badji et al., 1993; Beck et al., 1998; Dewan et al., 1992; 
82

Tab. 2. Effects of different basal media containing $4 \mu \mathrm{M}$ BA on in vitro shoot multiplication from cotyledonary node explants of $A$. mangium

\begin{tabular}{cccc}
\hline $\begin{array}{c}\text { Basal } \\
\text { medium }^{\mathrm{q}}\end{array}$ & $\begin{array}{c}\text { Percentage of } \\
\text { explant responded } \\
(\overline{\mathrm{X}} \pm \mathrm{SE})\end{array}$ & $\begin{array}{c}\text { Number of } \\
\text { shoots } \\
(\overline{\mathrm{X}} \pm \mathrm{SE})\end{array}$ & $\begin{array}{c}\text { Length of } \\
\text { shoots }(\mathrm{cm}) \\
(\overline{\mathrm{X}} \pm \mathrm{SE})\end{array}$ \\
\hline $\mathrm{MS}$ & $98.67 \pm 0.37 \mathrm{a}$ & $3.93 \pm 0.37 \mathrm{a}$ & $1.43 \pm 0.18 \mathrm{ab}$ \\
$\mathrm{MMS}_{1}$ & $98.33 \pm 1.67 \mathrm{a}$ & $2.87 \pm 0.36 \mathrm{ab}$ & $0.90 \pm 0.13 \mathrm{bc}$ \\
$\mathrm{MMS}_{2}$ & $63.33 \pm 1.69 \mathrm{c}$ & $2.13 \pm 0.55 \mathrm{~b}$ & $0.61 \pm 0.18 \mathrm{c}$ \\
$\mathrm{WPM}$ & $78.33 \pm 2.41 \mathrm{~b}$ & $2.87 \pm 0.52 \mathrm{ab}$ & $1.63 \pm 0.34 \mathrm{a}$ \\
\hline
\end{tabular}

Note: Values represent means \pm standard error of 20 explants per treatment in three repeated experiments. Means followed by the same letters are not significantly different by Duncan's multiple Range Test at $0.05 \%$ probability level. ${ }^{\mathrm{q}} \mathrm{MS}=$ Full strength MS medium; $\mathrm{MMS}_{1}=\mathrm{MS}$ with $1 / 2$ strength of major salts only; $\mathrm{MMS}_{2}=\mathrm{MS}$ with $1 / 2$ strength of both major and minor salts

Tab. 3. Effects of plant growth regulators on axillary shoot proliferation from cotyledonary node explants of $A$. mangium

\begin{tabular}{|c|c|c|c|c|c|}
\hline \multicolumn{4}{|c|}{$\begin{array}{l}\text { Plant growth } \\
\text { regulators }(\mu \mathrm{M})\end{array}$} & $\begin{array}{l}\text { Number of } \\
\text { shoots } \\
(\bar{X} \pm S E)\end{array}$ & $\begin{array}{c}\text { Length of } \\
\text { shoots }(\mathrm{cm}) \\
(\bar{X} \pm S E)\end{array}$ \\
\hline & $\mathrm{BA}$ & $\mathrm{Kn}$ & & & \\
\hline & 0 & 0 & & $0.92 \pm 0.19 \mathrm{hi}$ & $0.64 \pm 0.14 \mathrm{bcd}$ \\
\hline & 2.0 & - & & $1.42 \pm 0.19 \mathrm{ghi}$ & $0.86 \pm 0.10 \mathrm{bcd}$ \\
\hline & 4.0 & - & & $4.08 \pm 0.60 \mathrm{a}$ & $1.20 \pm 0.15 b$ \\
\hline & 6.0 & - & & $1.67 \pm 0.43 \mathrm{fghi}$ & $0.63 \pm 0.19 \mathrm{bcd}$ \\
\hline & 8.0 & - & & $2.42 \pm 0.29 \mathrm{bcdefg}$ & $1.05 \pm 0.14 \mathrm{bcd}$ \\
\hline & - & 2.0 & & $1.17 \pm 0.21$ ghi & $0.80 \pm 0.16 \mathrm{bcd}$ \\
\hline & - & 4.0 & & $1.58 \pm 0.23$ fghi & $0.85 \pm 0.16 \mathrm{bcd}$ \\
\hline & - & 6.0 & & $3.25 \pm 0.43 \mathrm{abcd}$ & $1.16 \pm 0.18 b c$ \\
\hline & - & 8.0 & & $2.08 \pm 0.34$ defgh & $0.83 \pm 0.12 \mathrm{bcd}$ \\
\hline $\mathrm{BA}$ & NAA & IBA & $\mathrm{GA}_{3}$ & & \\
\hline 2.0 & 0.5 & - & - & $1.25 \pm 0.25 \mathrm{ghi}$ & $0.85 \pm 0.19 \mathrm{bcd}$ \\
\hline 2.0 & 1.0 & - & - & $1.08 \pm 0.26 \mathrm{ghi}$ & $0.83 \pm 0.18 \mathrm{bcd}$ \\
\hline 2.0 & 2.0 & - & - & $0.67 \pm 0.19 \mathrm{i}$ & $0.59 \pm 0.16 \mathrm{~cd}$ \\
\hline 4.0 & 0.5 & - & - & $3.75 \pm 0.70 \mathrm{a}$ & $1.00 \pm 0.10 \mathrm{bcd}$ \\
\hline 4.0 & 1.0 & - & - & $2.25 \pm 0.45 \mathrm{cdefgh}$ & $0.94 \pm 0.09 \mathrm{bcd}$ \\
\hline 4.0 & 2.0 & - & - & $1.92 \pm 0.43$ efghi & $0.66 \pm 0.13 \mathrm{bcd}$ \\
\hline 2.0 & - & 0.5 & - & $1.08 \pm 0.26 \mathrm{ghi}$ & $0.66 \pm 0.15 \mathrm{bcd}$ \\
\hline 2.0 & - & 1.0 & - & $0.92 \pm 0.23 \mathrm{hi}$ & $0.49 \pm 0.18 \mathrm{~d}$ \\
\hline 2.0 & - & 2.0 & - & $0.67 \pm 0.19 \mathrm{i}$ & $0.48 \pm 0.13 \mathrm{~d}$ \\
\hline 4.0 & - & 0.5 & - & $3.50 \pm 0.67 \mathrm{abc}$ & $0.86 \pm 0.14 \mathrm{bcd}$ \\
\hline 4.0 & - & 1.0 & - & $2.25 \pm 0.46$ cdefgh & $0.79 \pm 0.14 \mathrm{bcd}$ \\
\hline 4.0 & - & 2.0 & - & $1.67 \pm 0.41 \mathrm{fghi}$ & $0.71 \pm 0.15 \mathrm{bcd}$ \\
\hline 2.0 & - & - & 0.5 & $1.38 \pm 0.32$ ghi & $1.72 \pm 0.32 \mathrm{a}$ \\
\hline 2.0 & - & - & 1.0 & $1.13 \pm 0.23 \mathrm{ghi}$ & $0.73 \pm 0.18 \mathrm{bcd}$ \\
\hline 2.0 & - & - & 2.0 & $0.88 \pm 0.23 \mathrm{hi}$ & $0.65 \pm 0.18 \mathrm{bcd}$ \\
\hline 4.0 & - & - & 0.5 & $2.88 \pm 0.61$ abcdef & $1.82 \pm 0.17 \mathrm{a}$ \\
\hline 4.0 & - & - & 1.0 & $3.63 \pm 0.65 \mathrm{ab}$ & $2.09 \pm 0.30 \mathrm{a}$ \\
\hline 4.0 & - & - & 2.0 & $3.13 \pm 0.55$ abcde & $0.96 \pm 0.21 \mathrm{bcd}$ \\
\hline
\end{tabular}

Note: Values represent means \pm standard error of 20 explants per treatment. Means followed by the same letters are not significantly different by Duncan's multiple Range Test at $0.05 \%$ probability level
Galiana et al., 1991; Junior et al., 2004; Khalafalla and Daffalla, 2008; Mittal et al., 1989; Nandwani, 1995; Rout et al., 2008; Singh et al., 1993; Vengadesan et al., 2002b). In addition, Jeyakumar and Jayabalan (2002) in Psoralea corylifolia, Husain et al. (2008) in Pterocarpus marsupium, Pradhan et al. (1998a) in Dalbergia sissoo, Rajeswari and Paliwal (2008) in Pterocarpus santalinus, Shyamkumar et al. (2003) in Terminalia chebula, Widiyanto et al. (2008) in Albizia falcataria also observed the superiority of BA over Kn on axillary shoot proliferation from seedling explants. On the contrary, Nandwani and Ramawat (1993) in Prosopsis cinerarea and Kumar (1992) in Baubinia purpurea found $\mathrm{Kn}$ as superior cytokinin to $\mathrm{BA}$ in in vitro shoot multiplication. The differential effects of $\mathrm{BA}$ and $\mathrm{Kn}$ on in vitro axillay shoot proliferation might be due to the different mode of action of $\mathrm{BA}$ and $\mathrm{Kn}$ during shoot development (Widiyanto et al., 2008).

Inclusion of NAA or IBA along with BA had no significant effect on both proliferation and elongation of axillary shoots. Average number of shoots and average length of shoots both were markedly reduced in all auxin-cytokinin combinations. Cotyledonary nodes produced highest $3.75 \pm 0.70$ shoots on medium containing $4.0 \mu \mathrm{M} \mathrm{BA}+$ $0.5 \mu \mathrm{M}$ NAA and the length of shoots was $1.00 \pm 0.10$ $\mathrm{cm}$ in that medium. The results revealed that exogenous auxin was not essential to initiate shoot bud formation, which also indicated the antagonistic effect of NAA or IBA with $\mathrm{BA}$ on in vitro shoot proliferation of $A$. mangium. Vengadesan et al. (2002b) also observed that auxins (NAA, IBA and IAA) along with BA were not effective for shoot proliferation from cotyledonary nodes of $A c a-$ cia sinuata. In Acacia senegal similar results were reported by Khalafalla and Daffalla (2008). This finding is also in agreement with Mallikarjuna and Rajendrudu (2009) in Holarrhena antidysenterica, Hussain et al. (2007) in Sterculia urens. Garland and Stoltz (1981) demonstrated that

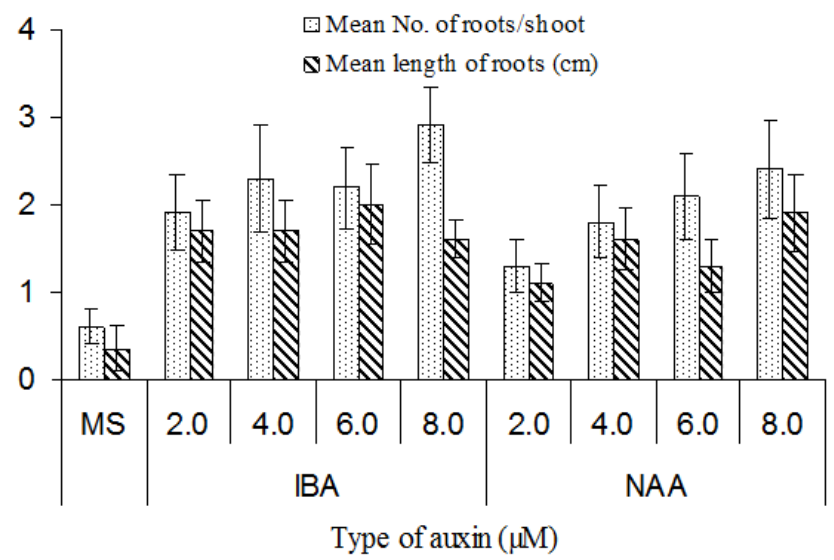

Fig. 2. Effects of auxins (IBA and NAA) on adventitious rooting of in vitro derived microshoots of $A$. mangium 
in a number of cases, cytokinins alone are enough for optimal shoot multiplication as also indicated by the works of Amin and Jaiswal (1993) and Aliou et al. (2006). Many researchers suggested that incorporation of low level auxin with BA enhanced shoot induction in different tree species, including Acacia catechu (Kaur et al., 1998), Acacia seyal (Al-wasel, 2000), Acacia tortilis (Nandwani, 1995), Aegle marmelos (Nayak et al., 2007), Colutea istria (Hegazi and Gabr, 2010), Nyctanthes arbor-tristis (Siddique et al., 2006), Pterocarpus marsupium (Husain et al., 2008) and Terminalia belerica (Rathore et al., 2008).

The effect of $\mathrm{GA}_{3}$ in combination with BA revealed that $\mathrm{GA}_{3}$ had no stimulatory effect on the shoot multiplication although shoot elongation was somewhat enhanced by the addition of $\mathrm{GA}_{3}$. Shoot length was increased maximum $0.89 \mathrm{~cm}$ upon the addition of $1.0 \mu \mathrm{M} \mathrm{GA}_{3}$ to the medium containing $4.0 \mu \mathrm{M} \mathrm{BA}$. When $\mathrm{GA}_{3}$ was incorporated at higher concentration than $1.0 \mu \mathrm{M}$, explants showed no elongation of shoots rather reduction in shoot number. Similar observation was recorded by Bhuyan et al. (1997) in Murraya koenigii, who observed maximum 0.6 $\mathrm{cm}$ elongation upon the addition of $0.4 \mathrm{mg} / \mathrm{l}(1.15 \mu \mathrm{M})$ $\mathrm{GA}_{3}$ to the medium containing $5.0 \mathrm{mg} / \mathrm{l}(22.2 \mu \mathrm{M}) \mathrm{BA}$. Vengadesan et al. (2000, 2002a, 2002b and 2003) also demonstrated that $\mathrm{GA}_{3}$ at low level could enhance shoot elongation in Acacia sinuata.

Microshoots attained 2-4 cm in length were cultured on auxin free medium and poor rooting was observed in auxin free MS medium. Rooting frequency was enhanced considerably when either IBA or NAA at different concentrations were added to MS medium. The use of IBA in the culture medium remarkably influenced the rate of root induction (Fig. 1D) than NAA. Among the different concentrations of IBA tested, maximum number of roots per shoot and longest roots having considerable lateral roots were obtained with $8.0 \mu \mathrm{M} \mathrm{IBA}$ (Fig. 1E). NAA was found to be less effective than IBA regarding rooting of microshoots. However, the roots produced by NAA were thin, delicate and hairy in nature. In this study, IBA was proved to be best auxin as comparable to NAA with regard to all rooting parameters. Documented literature shows that IBA has been found suitable for rooting in a number of tree species like Acacia mearnsii (Beck et al., 1998), Acacia nilotica (Dhabhai et al., 2010), Acacia senegal (Khalafalla and Daffalla, 2008), Acacia tortilis (Ali, 2009; Nandwani, 1995), Baubinia variegata (Mathur and Mukunthakumar, 1996), Dalbergia latifolia (Swamy et al., 1992), D. sissoo (Joshi et al., 2003; Pradhan et al., 1998a), Parkinsonia aculeata (Mathur and Mukunthakumar, 1996), Phellodendron amurense (Azad et. al., 2005, 2009), Pterocarpus marsupium (Husain et al., 2008) and Syzygium cuminii (Yadav et al., 1990 ).

After successful rooting of microshoots, attempts were taken to establish regenerated plantlets onto soil. Plantlets had been transferred to small plastic pots containing soil mix (garden soil: compost, 1:1) and maintained under humid ex vitro condition in the growth room (Fig. 1F). The in vitro derived plantlets acclimated better under $e x$ vitro condition when they were maintained in growth room for 25 days before transferring them to outdoor condition. Finally, 65\% transplanted plantlets were survived and acclimated well under ex vitro condition after 25 days of transplantation.

\section{Conclusions}

The described strategy demonstrates an efficient system of in vitro clonal propagation of $A$. mangium via cotyledonary node explants, which could play a significant role in large scale plantlet production all around the year, as well as in wide plantation and in conservation of this plant's genetic resources.

\section{References}

Abbas H, Qaiser M, Naqve AB (2010). Rapid in vitro multiplication of Accaia nilotica subsp. hemisperica, a critically endangered endemic taxon. Pak J Bot 42(6):4087-4093.

Ahmad DH (1991). Micropropagation of Acacia mangium from aseptically germinated seedlings. J Trop Forest Sci 3(3):204208.

Ahuja MR (1993). Microprapagation of woody plants. Kluwer Academic Publ., Dordrechet. The Netherlands, 507 p.

Ali YH (2009). Tissue culture in Sudan forest in vitro germination and micropropagation of Acacia tortilis subspp. spirocarpa, a multipurpose forest tree. J Genetic Eng Biotech 7(1):5-10.

Aliou N, Mamadou SD, Yayekene GD (2006). In vitro regeneration of adult trees of Bambusa vulgaris. Afr J Biotech 5:1245-1248.

Al-Wasel AS (2000). Micropropagation of Acacia seyal Del. in vitro. J Arid Env 46(4):425-431.

Amin MN, Jaiswal VS (1993). In vitro response of apical bud explants from immature trees of Jackfruit (Artocarpus heterophyllus). Plant Cell Tiss Org Cult 33:59-65.

Amin MN, Razzaque MA, Akhter S (1992). Axillary shoot proliferation and adventitious rooting in vitro of carambola (Averrhoa carambola L.). Plant Tissue Cult 2:7-13.

Amin SMR, Ali MO, Fattah MIM (1995). Eucalypts in Bangladesh. Proc A Seminar held at the Bangladesh Agricultural Research Council, 73 p.

Anis M, Hussain MK, Shahzad A (2005). In vitro plantlet regeneration of Pterocarpus marsupium Roxb. an endangered leguminous tree. Curr Sci 88:861-863.

Ara A, Hoque MI, Sarker RH, Haque MM (1991). In vitro propagation of Sesbania grandiflora L. Plant Tiss Cult 1(2):79-84.

Azad MAK, Yokota S, Begum F, Yoshizawa N (2009). Plant regeneration through somatic embryogenesis of a medicinal plant, Phellodendron amurense Rupr. In Vitro Cell Dev Biol 
84

Plant 45(4):441-449.

Azad MAK, Yokota S, Ohkubo T, Andoh Y, Yahara S, Yoshizawa $\mathrm{N}$ (2005). In vitro regeneration of the medicinal woody plant Phellodendron amurense Rupr. through excised leaves. Plant Cell Tiss Org Cult 80:43-50.

Badji S, Mairone Y, Merlin G, Danthu P, Neville P, Collonna JP (1993). In vitro propagation of the gum arabic tree (Acacia senegal (L.)Willd) 1. Developing a rapid method for producing plants. Plant Cell Rep 12:629-633.

Barik DP, Naik SK, Mudgal A, Chand PK (2007). Rapid plant regeneration through in vitro axillary shoot proliferation of butterfly pea (Clitoria ternatea L.)-a twining legume. In Vitro Cell Dev Biol Plant 43:144-148.

Beck SL, Dunlop RW, Staden JV (1998). Micropropagation of Acacia mearnsii from ex vitro material. Plant Growth Reg 26:143-148.

Berger K, Schaffner W (1995). In vitro propagation of the leguminous tree Swartzia madegascariensis. Plant Cell Tiss Org Cult 40:289-291.

Bhuyan AK, Pattnaik S, Chand PK (1997). Micropropagation of curry leaf tree (Murraya koenigii (L.) Sperng.) by axillary proliferation using intact seedlings. Plant Cell Rep 16:779782.

Bonga JM, von Aderkas P (1992). In vitro culture of trees. Kluwer Academic Publ, Dordrechet, The Netherlands, 236 p.

Deberg PC, Read RE (1990). Micropropagtaion, 1-12 p. In: Debergh PC, Zimmerman RH (Eds.). Micropropagation: Technology and Application, Kluwer Academic Publ., Dordrecht, The Netherlands.

Dewan A, Nanda K, Gupta SC (1992). In vitro micropropgation of Acacia nilotica subsp. indica Bernan via cotyledonay nodes. Plant Cell Rep 12:18-21.

Dhabhai K, Sharma MM, Batra A (2010). In vitro clonal propagation of Acacia nilotica (L.)-a nitrogen fixing tree. Researcher 2(3):7-11.

Galiana A, Tibok A, Duhoux E (1991). In vitro propagation of the nitrogrn fixing tree-legume Acacia mangium Willd, Plant and Soil 135:151-159.

Garland P, Stoltz LP (1981). Micropropagation of Pissardi plum. Ann Bot 48:387-389.

Hegazi GAE, Gabr MF (2010). Overcoming early shoot senescence of Colutea istria Miller propagated in vitro. J Am Sci 6(12):1733-1738.

Hossain MK, Islam SA, Zashimuddin M, Tarafder MA, Islam QN (1997). Growth and biomass production of some Acacia and Eucalyptus species in degenerated sal forest areas of Bangladesh. The Ind For 123(3):211-217.

Huang FH, Al-Khayri JM, Gbur E (1994). Micropropagation of Accaia mearnsii. In Vitro Cell Dev Biol Plant 30:70-74.

Husain MK, Anis M, Shahzad A (2008). In vitro propagation of a multipurpose leguminous tree (Pterocarpus marsupium Roxb.) using nodal explants. Acta Physiol Plant 30:353359 .
Hussain TM, Chandrasekhar T, Gopal GR (2007). High frequency shoot regeneration of Sterculia urens Roxb. an endangered tree species through cotyledonary node cultures. Afr J Biotech 6(14):1643-1649.

Islam MM, Amin ASMR, Sarker SK (2003). Invasive Allien Species in South-Southeast Asia, National Reports \& Directory of Resources. Proc The Global Invasive Species Programe, 7-20 p.

Jeyakumar M, Jayabalan N (2002). In vitro plant regeneration from cotyledonary node of Psoralea corylifolia L. Plant Tiss Cult 2(2):125-129.

Jones TC, Batchelor CA, Harris PJC (1990). In vitro culture and propagation of Acacia species (A. bivenosa, A. holosericea, $A$. salicina, $A$. saligna and $A$. sclerosperma). Intl Tree Crops J 6:183-192.

Joshi I, Bisht P, Sharma VK, Uniyal DP (2003). Studies on effect of nutrient media for clonal propagation of superior phenotypes of Dalbergia sissoo Roxb. through tissue culture. Silvae Genet 52:143-147.

Junior NB, Soborsa R, Martinus-Coder MP (2004). In vitro multiplication of axillary buds of black wattle (Acacia mearnsii De Willd.). Revista Árvore 28(4):493-497.

Kaur K, Verma B, Kant U (1998). Plants obtained from the khair tree (Acacia catechu Willd.) using mature nodal explants, Plant Cell Rep 17:421-429

Khalafalla MM, Daffalla HM (2008). In vitro micropropagation and micrografting of gum Arabic tree (Acacia senegal (L.) Wild.). Int J Sustain Crop Prod 3(1):19-27.

Khan BM, Hossain MA, Hossain MM, Hossain MK (2004). Performance of eleven multipurpose legume seedlings grown in the Hill soils under nursery conditions in Bangladesh. Int J Agr Biol 6(2):346-349.

Kumar A (1992). Micropropagation of a mature leguminous tree Baubinia purpurea. Plant Cell Tiss Org Cult 31:257259.

Lane WD (1978). Regeneration of apple from shoot meristem tips. Plant Sci Let 13:281-285.

Lloyd GB, McCown BH (1980). Commercially feasible micropropagation of mountain laurel (Kalmia latifolia) by use of shoot tip culture. Comb Proc Int Plant Prop Soc 30:421-437.

Loh CS, Rao AN (1989). Clonal propagation of guava (Psidium guajava L.) from seedling and grafted plants and adventitious shoot formation in vitro. Sci Hort 39:31-39.

Mallikarjuna K, Rajendrudu G (2009). Rapid in vitro propagation of Holarrhena antidysenterica using seedling cotyledonary nodes. Biol Plant 53(3):569-572.

Mathur J, Mukunthakumar S (1996). Micropropagation of Baubinia veriegata and Parkensonia aculeata from nodal explants of mature trees. Plant Cell Tiss Org Cult 28:169175.

Mittal A, Agarwal R, Gupta SC (1989). In vitro development of plantlets from axillary buds of Acacia auriculiformis-a leguminous tree. Plant Cell Tiss Org Cult 19:65-70. 
Murashige T, Skoog F (1962). A revised medium for rapid growth and bioassays with tobacco cultures. Physiol Plant 15(3):473-497.

Nandwani D (1995). In vitro micropropagation of a tree legume adapted to arid lands Acacia tortilis subsp. Raddiana. Ann Sci For 52:183-189.

Nandwani D, Ramawat KG (1993). In vitro plantlet formation through juvenile and mature explants in Prosopsis cineraria. Ind J Exp Biol 31:156-160.

Nayak P, Behera PR, Manikkannan T (2007). High frequency plantlet regeneration from cotyledonary node cultures of Aegle marmelos (L.) Corr. In Vitro Cell Dev Biol Plant 43:231-236.

Pradan C, Kar S, Pattnaik SK, Chand PK (1998a). Propagation of Dalbergia sissoo Roxb. through in vitro shoot proliferation from cotyledonary nodes. Plant Cell Rep 18:122-126.

Pradan C, Pattnaik SK, Chand PK (1998b). Rapid in vitro propagation of East Indian rosewood (Dalbergia latifolia Roxb.) through high frequency shoot proliferation from cotyledonary nodes. J Plant Biochem Biotechnol 7:61-64.

Rahman MA, Blake J (1988). Factors effecting in vitro proliferation and rooting of shoots of jackfruit (Artocarpus heterophyllus Lam.). Plant Cell Tiss Org Cult 13:179-187.

Rajeswari V, Paliwal K (2008). In vitro plant regeneration of red sanders (Pterocarpus santalinus L.f.) from cotyledonary nodes. Ind J Biotech 2:541-546.

Rathore P, Suthar R, Purohit SD (2008). Micropropagation of Terminalia bellerica Roxb. from juvenile explants. Ind J Biotech 7:246-249.

Rout GR, Senpati SK, Aparajeta S (2008). Micropropagation of Acacia chundra (Roxb.) DC. Hort Sci 35:22-26.

Ruredzo TZ, Hanson J (1993). Plant recovery from seedling derived shoot tips of Faidherbia albida grown in vitro. Agrofor Syst 22:59-65.

Saito Y, Kojima K, Ide Y, Sasaki S (1993). In vitro propagation from axillary buds of Acacia mangium, a legume tree in the tropics. Plant Tiss Cult Let 10(2):163-168.

Shyamkumar B, Anjaneyulu C, Giri C (2003). Multiple shoot induction from cotyledonary node explants of Terminalia chebula. Biol Plant 47(4):585-588.

Siddique I, Anis M, Jahan AA (2006). Rapid multiplication of Nyctanthes arbor-tristis through in vitro axillary shoot proliferation. World J Agr Sci 2(2):188-192.
Singh HP, Singh RPS, Saxena KP, Singh RK (1993). In vitro bud break in axillary nodal segments of mature trees of Acacia nilotica. Ind Plant Physiol 36(1):21-24.

Swamy BVR, Himabindu K, Sita GL (1992). In vitro micropropagation of elite rosewood (Dalbergia sissoo Roxb.). Plant Cell Rep 11:126-131.

Tiwari SK, Kashyap MK, Ujjaini MM, Agrawal AP (2002). In vitro propagation of Lagerstromia parviflora Roxb. from adult tree. Ind J Exp Biol 40:212-215.

Uddin MS, Nasirujjaman K, Zaman S, Reza MA (2005). Regeneration of multiple shoots from different explants viz. shoot tip, nodal segment and cotyledonary node of in vitro grown seedlings of Peltophorum pterocarpum (DC.) Backer ex K. Heyny. Biotechnol 4(1):35-38.

Umezawa T, Suzuki S, Shibata D (2008). Tree biotechnology of tropical Acacia. Plant Biotech 25:309-313.

Vengadesan G, Ganapathi A, Amutha S, Selvaraj N (2002a). In vitro propagation of Acacia species-a review. Plant Sci 163:663-671.

Vengadesan G, Ganapathi A, Amutha S, Selvaraj N (2003). High frequency plant regeneration from cotyledon callus of Acacia sinuata (Lour.) Merr. In Vitro Cell Dev Biol Plant 39:28-33.

Vengadesan G, Ganapathi A, Anand RP, Anbazhagan VR (2000). In vitro organogenesis and plant formation in Acacia sinuata (Lour.) Merr. Plant Cell Tiss Org Cult 6:23-28.

Vengadesan G, Ganapathi A, Prem R, Anbazhagan VR (2002b). In vitro propagation of Acaica sinuata (Lour.) Merr. via cotyledonary nodes. Agrofor Syst 55:9-15.

Widiyanto SN, Sari MD, Irwanto RR (2008). Effect of cytokinins and carbenicillin on in vitro axillary-shoot growth of Albizia (Albizia falcataria (L.) Fosberg). J Mat dan Sains 13(2):43-49.

Yadav U, Lal M, Jaiswal VS (1990). In vitro micropropagation of tropical fruit trees Syzygium cuminii L. Plant Cell Tiss Org Cult 21:87-92.

Zhang L, Chen J, Wang Y, Wu D, Xu M (2010). Phenolic extracts from Acacia mangium bark and their antioxidant activities. Molecules 15:3567-3577. 